\title{
Letter \\ Carbides Evolution in a Ni-16Mo-7Cr Base Superalloy during Long-Term Thermal Exposure
}

\author{
Fenfen Han *, Li Jiang, Xiangxi Ye, Yanling Lu, Zhijun Li and Xingtai Zhou \\ Center for Thorium Molten Salt Reactor System, Shanghai Institute of Applied Physics, Chinese Academy of \\ Sciences, Shanghai 201800, China; jiangli@sinap.ac.cn (L.J.); yexiangxi@sinap.ac.cn (X.Y.); \\ luyanling@sinap.ac.cn (Y.L.); lizhijun@sinap.ac.cn (Z.L.); zhouxingtai@sinap.ac.cn (X.Z.) \\ * Corresponding: hanfenfen@sinap.ac.cn; Tel.: +86-021-3919-4775 \\ Academic Editor: Mark T. Whittaker \\ Received: 30 March 2017; Accepted: 9 May 2017; Published: 12 May 2017
}

\begin{abstract}
The effect of long-term thermal exposure on the carbide evolution in a Ni-16Mo-7Cr base superalloy was investigated. The results show that $\mathrm{M}_{12} \mathrm{C}$ carbides are mainly precipitated on the grain boundaries during thermal exposure, and the primary massive $\mathrm{M}_{6} \mathrm{C}$ carbides can be completely transformed to $\mathrm{M}_{12} \mathrm{C}$ carbides in situ at temperatures above $750{ }^{\circ} \mathrm{C}$ for long-term thermal exposure. The transformation from $\mathrm{M}_{6} \mathrm{C}$ carbides to $\mathrm{M}_{12} \mathrm{C}$ carbides is attributed to the release of $\mathrm{C}$ atoms from $\mathrm{M}_{6} \mathrm{C}$, which results in the morphology changes of massive carbides, and stabilization of the sizes of $\mathrm{M}_{12} \mathrm{C}$ carbides precipitated on the grain boundaries.
\end{abstract}

Keywords: nickel base superalloy; carbide; thermal exposure; in situ transformation

\section{Introduction}

Molten salt reactor (MSR) is considered one of the most promising generation IV nuclear reactors due to its numerous operational and safety advantages [1-3]. A wrought Ni-16Mo-7Cr base superalloy named GH3535 is developed and used as the structure material for MSR applications. It is solid-solution strengthened with $16 \% \mathrm{Mo}$, and contains $7 \% \mathrm{Cr}$ for moderate oxidation resistance, which has superior corrosion resistance in molten fluoride salt and good mechanical properties [4-7]. The microstructure is composed of $\gamma$ matrix with equiaxial grain size of about $70 \mu \mathrm{m}$ and stringers of massive primary precipitates, which are determined as $\mathrm{M}_{6} \mathrm{C}$ carbides ( $\mathrm{M}$ represents the metal elements).

Because this alloy is supposed to be applied at about $700{ }^{\circ} \mathrm{C}$ for more than ten years in MSR, the thermal stability and mechanical properties of the alloy are always major concerns for designers. The previous research into the thermal stability of the Ni-16Mo-7Cr base alloy showed that the stringers of primary $\mathrm{M}_{6} \mathrm{C}$ carbides remained stable during the process of solid solution heat treatment [8]. Liu et al. studied the effect of long-term thermal exposure on microstructure and stress rupture properties of GH3535 superalloy, and suggested that the secondary carbide precipitated on the grain boundary is $\mathrm{M}_{12} \mathrm{C}$, which coexists with primary $\mathrm{M}_{6} \mathrm{C}$ carbides in the aged alloy at $700{ }^{\circ} \mathrm{C}$ [7], while Leitnaker et al. mentioned that only $\mathrm{M}_{12} \mathrm{C}$ exists in a Ni-16Mo-7Cr base alloy exposed at $815^{\circ} \mathrm{C}$ for $10,000 \mathrm{~h}$ [9]. Both studies emphasized that the precipitated carbide was $\mathrm{M}_{12} \mathrm{C}$ rather than $\mathrm{M}_{6} \mathrm{C}$, but did not mention whether the transformation of primary $\mathrm{M}_{6} \mathrm{C}$ to $\mathrm{M}_{12} \mathrm{C}$ carbides occurs during thermal exposure. Because the carbides play a major role in strengthening the alloy, it is worth evaluating the type and evolution of the carbides in the longer thermal exposure time at elevated temperatures.

In this study, the evolution of carbides in GH3535 alloy is systematically investigated in the temperature range of $600-800{ }^{\circ} \mathrm{C}$. The types, stability, and evolution of carbides are discussed and determined in this paper. 


\section{Materials and Methods}

The nominal chemical composition (wt. \%) of the investigated alloy in this study is: Mo, 16; Cr, $7 ; \mathrm{Fe}, 4 ; \mathrm{Mn}, 0.5 ; \mathrm{Si}, 0.5 ; \mathrm{C}, 0.05 ; \mathrm{Ni}$, balance. The master alloy was prepared by vacuum induction melt-furnace (VIM), followed by hot forging and rolling into rods with the diameter of $16 \mathrm{~mm}$ in the temperature range of $1150-1200{ }^{\circ} \mathrm{C}$. The specimens cut from the rods were solution heat-treated at $1177^{\circ} \mathrm{C}$ for $40 \mathrm{~min}$, followed by water quenching, and then placed in the furnaces at the temperatures of $600{ }^{\circ} \mathrm{C}, 650{ }^{\circ} \mathrm{C}, 700{ }^{\circ} \mathrm{C}, 750^{\circ} \mathrm{C}$, and $800^{\circ} \mathrm{C}$. The time intervals for each temperature were $1000 \mathrm{~h}$, $3000 \mathrm{~h}, 6000 \mathrm{~h}$, and 10,000 h. The thermally exposed specimens were removed from the furnace and cooled in air after thermal exposure. Then, these specimens were ground using metallographic SiC papers to \#2000, polished by diamond grinding paste, and chemically etched by a solution of $3 \mathrm{~g}$ $\mathrm{CuSO}_{4}+10 \mathrm{~mL} \mathrm{H}_{2} \mathrm{SO}_{4}+40 \mathrm{~mL} \mathrm{HCl}+50 \mathrm{~mL} \mathrm{H} \mathrm{O}_{2} \mathrm{O}$ with $20 \mathrm{~s}$ for microstructure observation.

A scanning electron microscope (MERLIN Compact, Carl Zeiss, Oberkochen, Germany) with voltage of $15 \mathrm{kV}$ was employed to observe the microstructure morphology of the specimens. An electron probe microanalyzer (EPMA-1720H, SHIMADZU, Kyoto, Japan) with voltage of $15 \mathrm{kV}$ and current of $50 \mathrm{nA}$ was used to quantitatively analyze the composition of the carbides. An X-ray diffraction (D8 Advance, Bruker, Madison, WI, USA) system with voltage of $40 \mathrm{kV}$ and current of $40 \mathrm{~mA}$ was used to identify the phase type in the alloy. The size of specimens used for SEM and EPMA analysis was $10 \mathrm{~mm} \times 10 \mathrm{~mm} \times 5 \mathrm{~mm}$, while the specimen used for XRD analysis was powder prepared by electrochemical extraction method. The exposed alloy as anode was electrolyzed in the solution of $\mathrm{CH}_{3} \mathrm{OH}$ and $\mathrm{HCl}$ (3:7) with voltage of $10 \mathrm{~V}$ for $24 \mathrm{~h}$. Then, the powder specimen was obtained from the achieved solution by centrifugal machine separation, followed by repeated cleaning by alcohol and air drying for XRD analysis.

\section{Results}

The evolution of the microstructures and mechanical properties of GH3535 alloy were investigated at $700{ }^{\circ} \mathrm{C}$ [7]. The focus of this research is mainly on the evolution of primary carbides at higher temperatures. Figure 1 shows the microstructure evolution of the experimental alloy exposed to $750{ }^{\circ} \mathrm{C}$ for various times. The heat-treated alloy consisted of equiaxed grains and primary $\mathrm{M}_{6} \mathrm{C}$ carbides distributed in the grain or on the grain boundary, as shown in Figure 1a. When the alloy is subjected to thermal exposure, the secondary carbides of $\mathrm{M}_{12} \mathrm{C}$ are precipitated on the grain boundary (as shown in Figure 1b-d), which were also identified in previous work [7]. For the alloy exposed for more than $3000 \mathrm{~h}$, the primary carbides were no longer dense, and lots of holes are observed inside of the massive primary carbides. The sizes of $\mathrm{M}_{12} \mathrm{C}$ carbides in the alloy exposed at $750{ }^{\circ} \mathrm{C}$ and $800{ }^{\circ} \mathrm{C}$ are shown in Figure 1e. At least 10 different SEM images with 10,000-fold magnification were used to determine the sizes of grain boundary carbides in the specimen with each exposure condition. Here, the size of $\mathrm{M}_{12} \mathrm{C}$ carbide is defined as the average data of the widths of the carbides in the vertical direction of the grain boundaries. It can be seen that the size of $\mathrm{M}_{12} \mathrm{C}$ carbide reached $450 \mathrm{~nm}$ after the alloy was exposed at $750{ }^{\circ} \mathrm{C}$ for $3000 \mathrm{~h}$ and it no longer increased afterwards. As the alloy was exposed at $800{ }^{\circ} \mathrm{C}$, the size of $\mathrm{M}_{12} \mathrm{C}$ no longer increased after $1000 \mathrm{~h}$ and the maximal size was about $700 \mathrm{~nm}$. However, for the alloy exposed at $700{ }^{\circ} \mathrm{C}$, the size of grain boundary carbide kept increasing with the rising of the exposure time (the data at $700{ }^{\circ} \mathrm{C}$ in Figure 1e refer to Ref. [10]). 

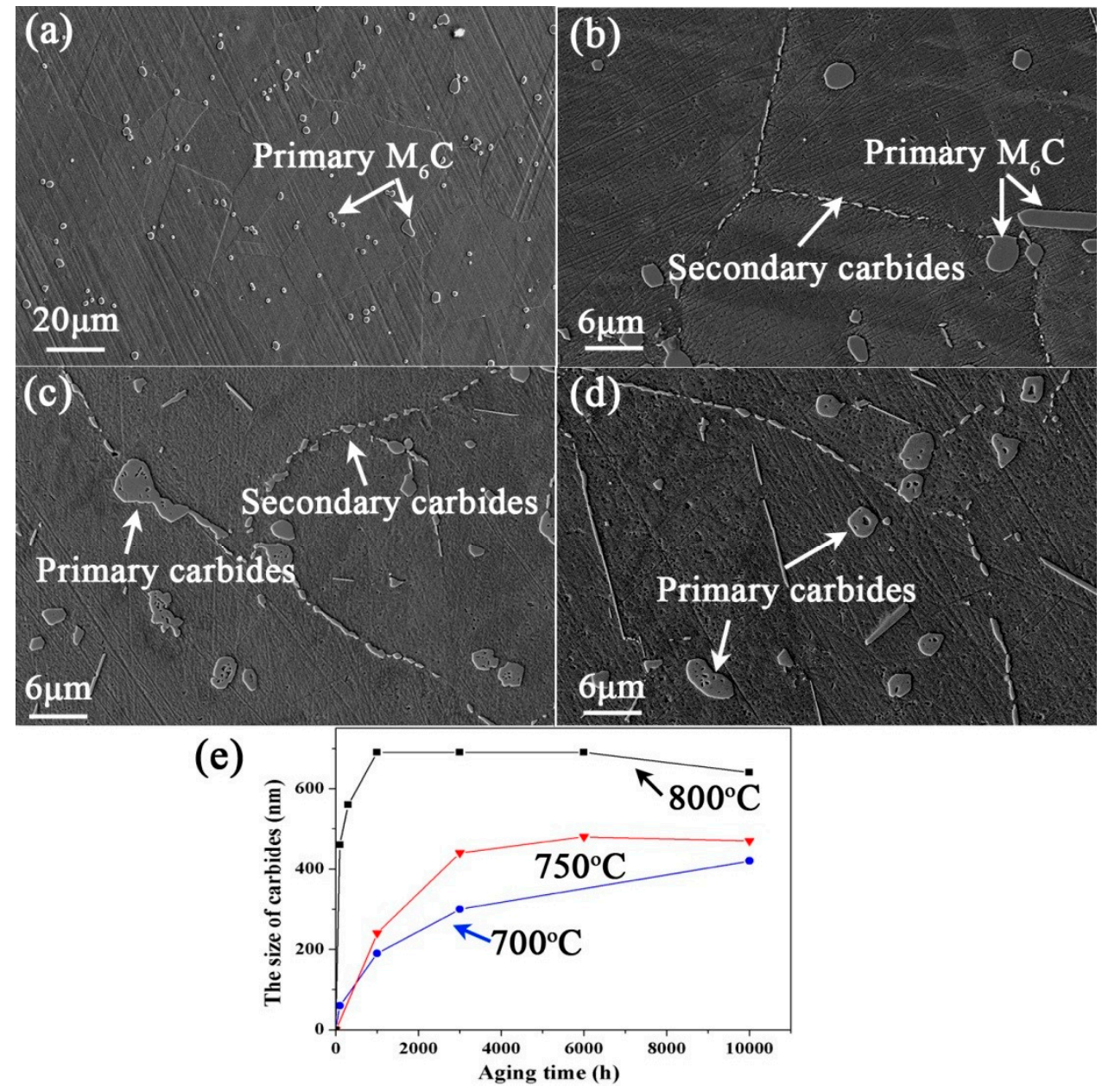

Figure 1. The microstructure of the alloy exposed at $750{ }^{\circ} \mathrm{C}$ for various times: (a) $0 \mathrm{~h}$ (heated alloy); (b) $1000 \mathrm{~h}$; (c) $3000 \mathrm{~h}$; (d) 10,000 h and (e) the size of carbides precipitated on the grain boundary. The data at $700{ }^{\circ} \mathrm{C}$ in Figure 1e referred to Ref. [10].

Figure 2 shows the morphologies of the primary carbides during the exposure process at $800{ }^{\circ} \mathrm{C}$ for various exposure times. After the alloy was exposed for $1000 \mathrm{~h}$, holes and cracks were apparent in the interior of the primary carbides, as shown in Figure 2a,b. With the increasing of the exposure time, more cracks were generated and the sizes of the holes obviously increased in the massive primary carbides (Figure 2c). The specimen without chemical etching is also presented in Figure $2 \mathrm{~d}$, and the holes and cracks can be observed clearly in the primary carbides. It is proved that the formation of these holes is caused by the thermal exposure.

The change in morphology of massive primary carbides may indicate the change in the composition, and thus EPMA quantitative analysis was also carried out for the primary carbides in the alloy exposed at various conditions, as shown in Figure 3. The data for each condition are the average data of at least ten primary carbides in the specimen. When the alloy is exposed at different temperatures for $10,000 \mathrm{~h}$, the $\mathrm{C}$ and $\mathrm{Cr}$ contents of the $\mathrm{M}_{6} \mathrm{C}$ carbides decrease by half at temperature above $750{ }^{\circ} \mathrm{C}$, while the $\mathrm{Si}$ and $\mathrm{Ni}$ contents of those increase (Figure 3a). For the alloy exposed at $750{ }^{\circ} \mathrm{C}$ and $800{ }^{\circ} \mathrm{C}$, the phenomenon of the composition change occurs after $3000 \mathrm{~h}$ and $1000 \mathrm{~h}$, respectively (Figure $3 b, c)$. 


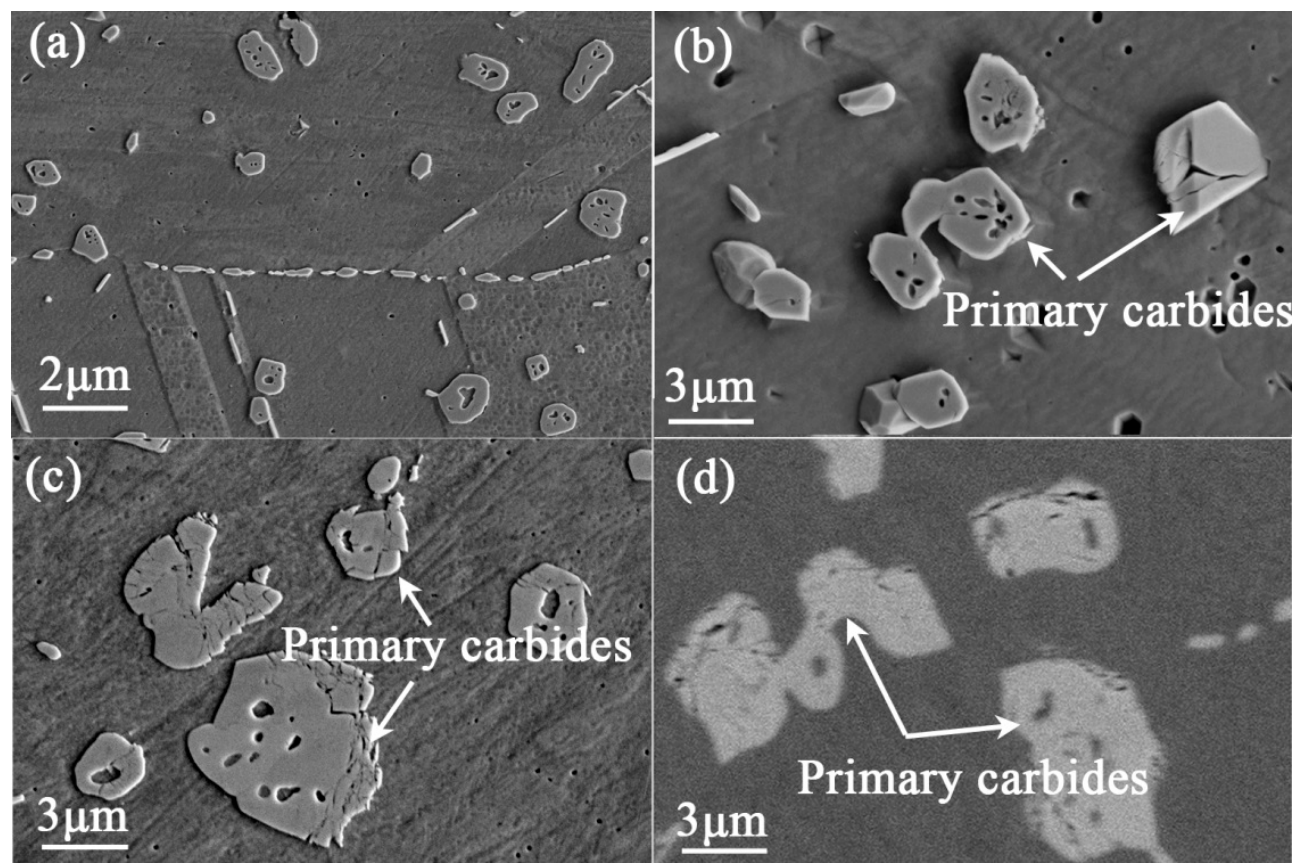

Figure 2. SEM images for the morphology of primary carbides in the alloy exposed at $800{ }^{\circ} \mathrm{C}$ with chemical etching: (a,b) $1000 \mathrm{~h}$; (c) $3000 \mathrm{~h}$ and without etching (d) $3000 \mathrm{~h}$.
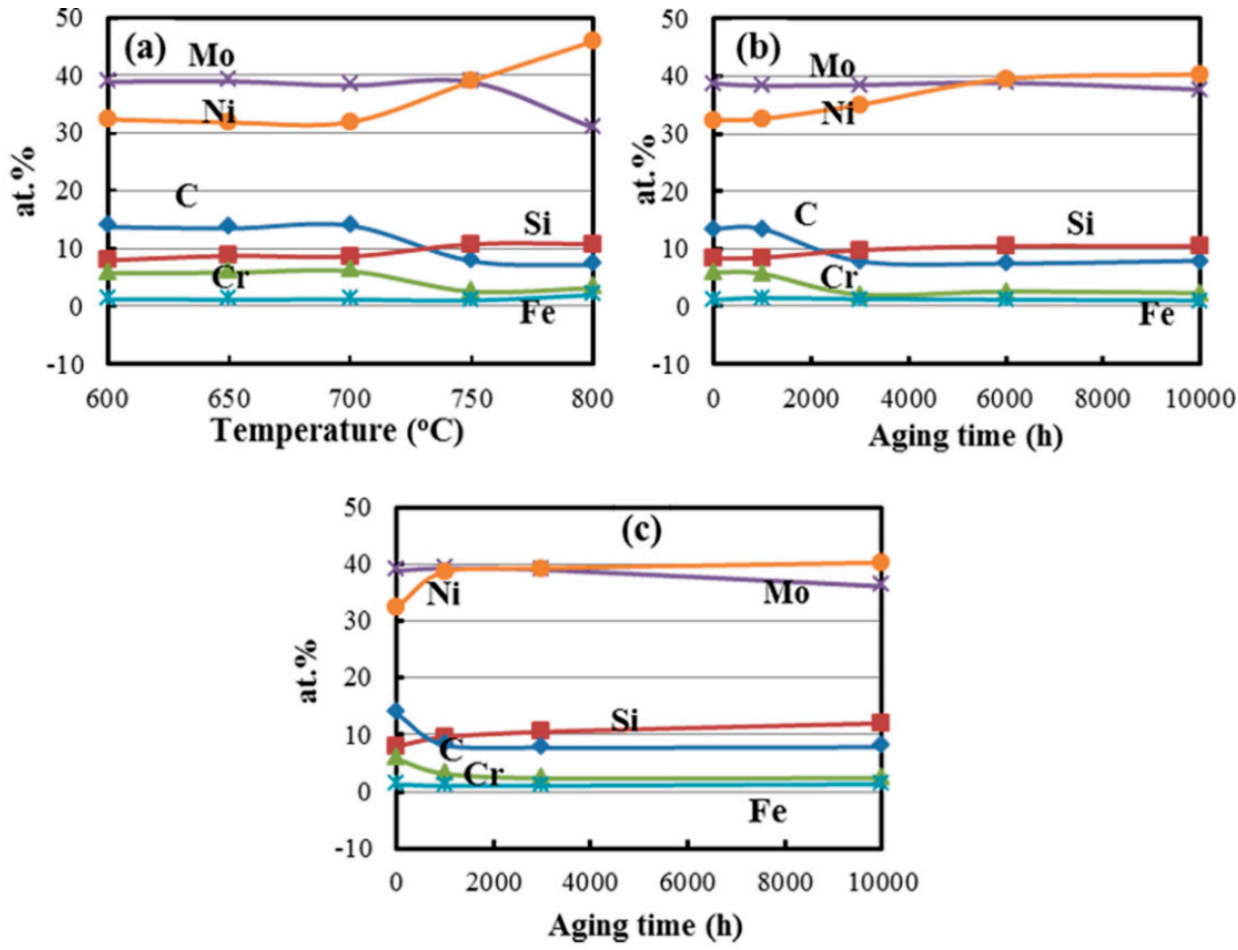

Figure 3. The elements evolution in massive primary carbides: (a) The alloy exposed for 10,000 h at different temperature; The alloy exposed at (b) $750{ }^{\circ} \mathrm{C}$ and (c) $800{ }^{\circ} \mathrm{C}$ for $10,000 \mathrm{~h}$.

In order to determine whether there is any type change of the primary carbides with the composition change in Figure 3, XRD analyses were employed on the powder of carbides obtained from the exposed alloys. Figure 4 shows $\mathrm{X}$-ray diffraction pattern of the specimen aged at $750{ }^{\circ} \mathrm{C}$ for various exposure times. For the heat-treated alloy, only $\mathrm{M}_{6} \mathrm{C}$ was detected in the carbides powder obtained by 
chemical extraction from the alloy, while only one type of carbide, $\mathrm{M}_{12} \mathrm{C}$, was detected for the alloy exposed longer than $3000 \mathrm{~h}$ and $10,000 \mathrm{~h}$. This suggests that the primary $\mathrm{M}_{6} \mathrm{C}$ carbides transform to $\mathrm{M}_{12} \mathrm{C}$ carbides in the thermal exposure process. According to the microstructure observation in Figure 1 and composition analyses in Figure 3, the transformation is in situ just through composition change and lattice reconfiguration of $\mathrm{M}_{6} \mathrm{C}$ carbides.

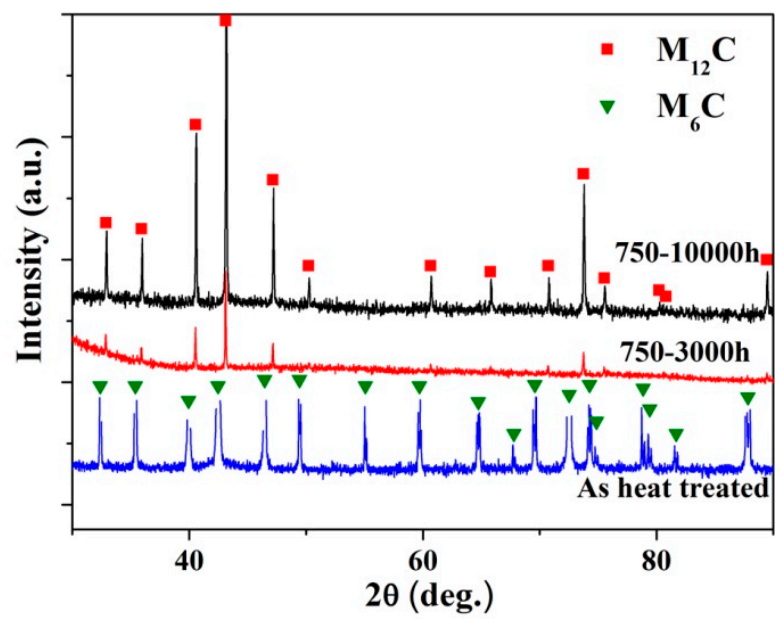

Figure 4. X-ray diffraction pattern of the specimen aged at $750{ }^{\circ} \mathrm{C}$ for various times.

\section{Discussion}

The original microstructure of heat-treated GH3535 alloy was characterized by stringers of massive primary $\mathrm{M}_{6} \mathrm{C}$ carbides. When the alloy is subjected to thermal exposure, $\mathrm{M}_{12} \mathrm{C}$ carbides are precipitated on the grain boundaries $[7,11]$. When the alloy was exposed to temperatures above $750{ }^{\circ} \mathrm{C}$ for a long time, the massive $\mathrm{M}_{6} \mathrm{C}$ carbides were transformed to $\mathrm{M}_{12} \mathrm{C}$ carbides (Figures 3 and 4). The findings in this work are different from the previous studies for the $\mathrm{GH} 3535$ alloy exposed at $700{ }^{\circ} \mathrm{C}$ with long-term thermal exposure, where two types of carbides coexist in the exposed alloy [11].

The crystal structures of the $\mathrm{M}_{12} \mathrm{C}$ and $\mathrm{M}_{6} \mathrm{C}$ carbides were almost identical, both of which are in $\mathrm{fcc}$ crystal structure. The major difference is that the number of carbon atoms in $\mathrm{M}_{12} \mathrm{C}$ carbide is half that in $\mathrm{M}_{6} \mathrm{C}$ in the unit cell, and the lattice parameter of the $\mathrm{M}_{12} \mathrm{C}$ carbide is a little smaller than that of $\mathrm{M}_{6} \mathrm{C}\left(\mathrm{M}_{12} \mathrm{C}, 1.089 \mathrm{~nm} ; \mathrm{M}_{6} \mathrm{C}, 1.105 \mathrm{~nm}\right)[12,13]$. Thus, the literature about the transformation from $\mathrm{M}_{6} \mathrm{C}$ to $\mathrm{M}_{12} \mathrm{C}$ is relatively scarce in nickel base superalloys. For the GH3535 alloy, in the matrix, the contents of alloying elements that form carbides gradually decrease due to the precipitation of $\mathrm{M}_{12} \mathrm{C}$ carbides on the grain boundaries, which can break the concentration balance of alloying elements in the alloy, and then result in the escape of $\mathrm{C}$ atoms from $\mathrm{M}_{6} \mathrm{C}$ carbides into the matrix (Figure 3). Consequently, the $\mathrm{M}_{6} \mathrm{C}$ carbides completely transform to $\mathrm{M}_{12} \mathrm{C}$ carbides by the transport of $\mathrm{C}$ atoms into the matrix due to the structural similarity of two kinds of carbides. This transformation has also been observed in cobalt-based alloys $[14,15]$. The large release of $C$ atoms from $\mathrm{M}_{6} \mathrm{C}$ carbides into matrix increases the velocity of nucleation and growth of secondary carbides precipitated on the grain boundaries, and thus increases their size until a new balance of $C$ concentration is achieved in the aged alloy. On the other hand, the obvious diffusion of $\mathrm{C}, \mathrm{Si}$, and $\mathrm{Cr}$ atoms across the phase interface between carbides and the matrix exists during the long-term thermal exposure (Figure 3 ), and the lattice parameter decreases in the transformation from $\mathrm{M}_{6} \mathrm{C}$ carbides to $\mathrm{M}_{12} \mathrm{C}$ carbides. We simplified the $\mathrm{M}_{6} \mathrm{C}$ and $\mathrm{M}_{12} \mathrm{C}$ carbides as $\mathrm{Ni}_{3} \mathrm{Mo}_{3} \mathrm{C}$ and $\mathrm{Ni}_{6} \mathrm{Mo}_{6} \mathrm{C}$ structures, respectively, and calculated their densities as $9.031 \mathrm{~g} / \mathrm{cm}^{3}$ and $9.517 \mathrm{~g} / \mathrm{cm}^{3}$ by dividing the atomic mass by volume in the unit cell $[12,16]$. Provided that the phase interface does not migrate, the change of the density of carbide particles will cause the so-called Kirkendall pores (Figure 2). Such a difference in the density can cause five pores with a 
diameter of $1 \mu \mathrm{m}$ in the spherical particle with a diameter of $10 \mu \mathrm{m}$, which is in good accordance with the morphologies shown in Figure 2c.

\section{Conclusions}

The effect of long-term thermal exposure on carbides evolution was systematically investigated in a $\mathrm{Ni}-16 \mathrm{Mo}-7 \mathrm{Cr}$ base alloy, and the main conclusions were as follows:

1. The secondary $\mathrm{M}_{12} \mathrm{C}$ carbides are mainly precipitated on the grain boundaries during thermal exposure, and their sizes reach stable state when the alloy is exposed at $750{ }^{\circ} \mathrm{C}$ and $800{ }^{\circ} \mathrm{C}$ for $3000 \mathrm{~h}$ and $1000 \mathrm{~h}$, respectively.

2. The primary massive $\mathrm{M}_{6} \mathrm{C}$ can be completely transformed to $\mathrm{M}_{12} \mathrm{C}$ in situ at higher temperatures above $750{ }^{\circ} \mathrm{C}$ through composition change and lattice reconfiguration.

3. The transformation from $\mathrm{M}_{6} \mathrm{C}$ carbides to $\mathrm{M}_{12} \mathrm{C}$ carbides is attributed to the release of $\mathrm{C}$ atoms from $\mathrm{M}_{6} \mathrm{C}$, which results in the morphology changes of massive carbides, and stabilization of the sizes of $\mathrm{M}_{12} \mathrm{C}$ carbides precipitated on the grain boundaries.

Acknowledgments: This work was supported by the National Natural Science Foundation of China (Grant No. 51601214, 51601213, 51501216, 51674237, and 51501217), the National Key Research and Development Program (2016YFB0700404).

Author Contributions: Fenfen Han, Li Jiang, and Xiangxi Ye conceived and designed the experiments; Fenfen Han performed the experiments; Zhijun Li and Yanling Lu analyzed the data; Li Jiang contributed the analysis tools; Fenfen Han wrote the paper; Xiangxi Ye and Xingtai Zhou revised the paper.

Conflicts of Interest: The authors declare no conflict of interest.

\section{References}

1. LeBlanc, D. Molten salt reactors: A new beginning for an old idea. Nucl. Eng. Des. 2010, 240, 1644-1656. [CrossRef]

2. Mathieu, L.; Heuer, D.; Brissot, R.; Garzenne, C.; LeBrun, C.; Lecarpentier, D.; Liatard, E.; Loiseaux, J.-M.; Méplan, O.; Merle-Lucotte, E.; et al. The thorium molten salt reactor: Moving on from the MSBR. Prog. Nucl. Energ. 2006, 48, 664-679. [CrossRef]

3. Alekseev, P.N.; Belov, I.A.; Ponomarev-Stepnoi, N.N.; Kukharkin, N.E.; Subbotin, S.A.; Udyanskii, Y.N.; Chibinyaev, A.V.; Shchepetina, T.D.; Fomichenko, P.A. MARS low-power liquid-salt micropellet-fuel reactor. At. Energy 2002, 93, 537-546. [CrossRef]

4. Li, X.L.; He, S.M.; Zhou, X.T.; Li, Z.J.; Zou, Y.; Li, A.G.; Yu, X.H. Improving oxidation resistance of Ni-16Mo-7Cr-4Fe nickel-based superalloy by yttrium microalloying. Nucl. Sci. Technol. 2015, 26, 33-39.

5. Shrestha, S.L.; Bhattacharyya, D.; Yuan, G.Z.; Li, Z.J.; Budzakoska-Testonea, E.; De Los Reyesa, M.; Drewa, M.; Edwards, L. Creep resistance and material degradation of a candidate $\mathrm{Ni}-\mathrm{Mo}-\mathrm{Cr}$ corrosion resistant alloy. Mater. Sci. Eng. A 2016, 674, 64-75. [CrossRef]

6. Hou, J.; Yu, G.J.; Zeng, C.L.; Ai, H.; Xie, R.B.; Chen, Y.J.; Zhou, X.T.; Xie, L.D.; Wang, J.Q. Effects of exposing duration on corrosion performance in weld joint of $\mathrm{Ni}-\mathrm{Mo}-\mathrm{Cr}$ alloy in FLiNaK molten salt. J. Fluorine Chem. 2016, 191, 110-119. [CrossRef]

7. Liu, T.; Dong, J.S.; Wang, L.; Li, Z.J.; Zhou, X.T.; Lou, L.H.; Zhang, J. Effect of long-term thermal exposure on microstructure and stress rupture properties of GH3535 superalloy. J. Mater. Sci. Technol. 2015, 31, 269-279. [CrossRef]

8. Gehlbach, R.E.; McCoy, H.E. Phase instability in Hastelloy N. In Proceedings of the International Symposium on Structural Stability in Superalloys, Seven Springs, PA, USA, 4-6 September 1968; pp. 346-366.

9. Leitnaker, J.M.; Potter, G.A.; Bradley, D.J.; Franklin, J.C.; Laing, W.R. The composition of eta carbide in hastelloy $\mathrm{N}$ after aging $10,000 \mathrm{~h}$ at $815^{\circ} \mathrm{C}$. Metall. Trans. A 1978, 9, 397-400. [CrossRef]

10. Han, F.F.; Zhou, B.M.; Huang, H.F.; Leng, B.; Lu, Y.L.; Li, Z.J.; Zhou, X.T. Effect of long-term thermal exposure on the hot ductility behavior of GH3535 alloy. Mater. Sci. Eng. A 2016, 673, 299-306. [CrossRef] 
11. Liu, T.; Dong, J.S.; Wang, L.; Lou, L.H. Effect of silicon on microstructure and stress rupture properties of a corrosion resistant Ni-based superalloy during long term thermal exposure. Mater. Sci. Eng. A 2016, 656, 75-83. [CrossRef]

12. Fraker, A.C.; Stadelmaier, H.H. The Eta Carbides of Molybdenum-Iron, Molybdenum-Cobalt and Molybdenum-Nickel. Trans. Metall. Soc. AIME 1969, 245, 847-850.

13. Jiang, L.; Zhang, W.Z.; Xu, Z.F.; Huang, H.F.; Ye, X.X.; Leng, B.; Yan, L.; Li, Z.J.; Zhou, X.T. $\mathrm{M}_{2} \mathrm{C}$ and $\mathrm{M}_{6} \mathrm{C}$ carbide precipitation in Ni-Mo-Cr based superalloys containing silicon. Mater. Des. 2016, 112, 300-308. [CrossRef]

14. Hamar-Thibault, S.; Durand-Charre, M.; Andries, B. Carbide transformations during aging of wear-resistant Cobalt alloys. Metall. Trans. A 1982, 13,545-550. [CrossRef]

15. Cho, K.; Schuh, C.A. W-based amorphous phase stable to high temperatures. Acta Mater. 2015, 85, 331-342. [CrossRef]

16. Newsam, J.M.; Jacobson, A.J.; McCandlish, L.E.; Polizzotti, R.S. The structures of the $\eta$-carbides $\mathrm{Ni}_{6} \mathrm{Mo}_{6} \mathrm{C}$, $\mathrm{Co}_{6} \mathrm{Mo}_{6} \mathrm{C}$ and $\mathrm{Co}_{6} \mathrm{Mo}_{6} \mathrm{C}_{2}$. J. Solid State Chem. 1988, 75, 296-304. [CrossRef]

(c) 2017 by the authors. Licensee MDPI, Basel, Switzerland. This article is an open access article distributed under the terms and conditions of the Creative Commons Attribution (CC BY) license (http://creativecommons.org/licenses/by/4.0/). 